\title{
The Story of Chinese Characters (0076-0085) when Translated on Korean Pronunciation
}

\author{
Hyeonhi Regina Park1, Kunjoo Daegon-Andrea Kim², Jiah Anna Kim³, Rosa Kim4, Alain Hamon5, Sohwa \\ Therese Kim${ }^{6}$, Sangdeog Augustin $\mathrm{Kim}^{7^{\star}}$ \\ 1Department of Elderly care and welfare, Joongbu University, Kumsan, Republic of Korea, ROK \\ 2Department of History, Yonsei University, Seoul, ROK \\ ${ }^{3}$ Department d'Expertise economique, Universite de Paris-Est Creteil, Paris, France \\ ${ }^{4}$ Specialite d'Economie politique, Ecole des Hautes Etudes en Sciences Sociales (EHESS), Paris, France \\ 5L'Ecole Internationale Jean-Mermoz, Abidjan, Cote d'Ivoire \\ ${ }^{6}$ Department of French language and literature, Seoul Women's University, Seoul, ROK), \\ ${ }^{7}$ Department of Companion Animal and Animal Resources Science, Joongbu University, Kumsan, ROK \\ *Corresponding Author \\ Sangdeog Augustin Kim
}

\section{Article History}

Received: 18.12 .2019

Accepted: 25.12 .2019

Published: 30.12 .2019

\begin{abstract}
It is well known that Chinese characters are common base of the East Asian people. The present researchers investigated the translation of Tcheonzamun (Thousand character essay) poem, and they studied the analyses of Chinese characters. And the researchers became to know that the method of using Korean pronunciation is good for both Tcheonzamun analyses and translation of Chinese characters. The researchers chose Chinese characters by random and named them from 0076 to 0085 . The present researchers continued to study the meaning of the Chinese characters through the pronunciation of several parts of the letter. And the researchers analyzed the Chinese characters and tried to assemble the separated parts in several ways. The researchers assembled these parts through the sound of separated parts or though the meaning of the separated parts. For example, on $0076, \mathrm{Zi}$ 知) = Hwasal(矢) hana(一) gam(Ü); Hwasal(矢) and hana(一) are through the meaning of the parts, while gam(Ü) is the sound of the separated part. The letter of $0079 \mathrm{Hyo}$ (孝): "You might be disappointed with the unfaithful attitude of your children!" Hyo(孝) = Sib(十) sib(十) za(子); Sib sib za $\rightarrow$ Seob seob zi!; 섭섭지!(You are disappointed!) (The original meaning).
\end{abstract}

Keywords: Chinese characters, Korean pronunciation, meaning of the separated parts, sound of separated parts, meaning of the Chinese character.

\section{INTRODUCTION}

It is well known that Chinese characters are common base of the East Asian people $[1,2]$. The present researchers investigated the translation of Tcheonzamun (Thousand character essay) poem [3], and they studied the analyses of Chinese characters [4]. And the researchers became to know that the method of using Korean pronunciation is good for both Tcheonzamun analyses and translation of Chinese characters. Therefore, the researchers continued to do the analyses of Chinese characters, and they have tried to find the appropriate meaning of Chinese characters through Korean pronunciation.

\section{Materials and Methods}

The present researchers chose Chinese characters by random and named them from 0076 to 0085 . And the researchers analyzed the Chinese characters and tried to assemble the separated parts in several ways. The researchers assembled these parts through the sound of separated parts or though the meaning of the separated parts. For example, on 0076, Zi(知) = Hwasal(矢) hana( 一) gam(Ü); Hwasal(矢) and hana(一) are through the meaning of the parts, while gam(Ü) is the sound of the separated part.

Copyright @ 2019: This is an open-access article distributed under the terms of the Creative Commons Attribution license which permits unrestricted use, distribution, and reproduction in any medium for non commercial use (NonCommercial, or CC-BY-NC) provided the original author and source are credited. 


\section{RESULTS AND DISCUSSION}

The present researchers continued to study the meaning of the Chinese characters through the pronunciation of several parts of the letter.

Number, Pronunciation of the Chinese character (Chinese character): Meaning in Korean pronunciation of the Chinese character, Korean pronunciation in Korean alphabet.

0076 Zi(知): "I can start shooting an arrow at the first time!"

Zi(知) = Hwasal(矢) hana(一) gam(Ü); Hwasal hana gam; 화살 하나 감(an arrow is shot). (The original meaning.)

'I know it.' (The current meaning.)

0077 Beob(法): "You must respect the law!"

Beob(法) = Su(水) geo(去); Sug yeo; 숙여 (Hang down!). (The original meaning.)

'The law.' (The current meaning.)

$0078 \mathrm{Su}$ (秀): "He(or She, I, You, They) is(am, are) easily angry with others."

$\mathrm{Su}($ 秀 $)$ = Hwa(禾) nae(乃); Hwa nae; 화 내('Be angry' or 'Be angry to other!'). (The original meaning.)

'He(or She, I, You, They) is(am, are) excellent!' (The current meaning.)

0079 Hyo(孝): "You might be disappointed with the unfaithful attitude of your children!"

Hyo(孝) = Sib(十) sib(十) za(子); Sib sib za $\rightarrow$ Seob seob zi!; 섭 섭지!(You are disappointed!) (The original meaning.)

'Respecting one's parent(s).' (The current meaning.)

0080 No (老): "You(l, He, She, They) might be regrettable because of the children!"

No $($ 老) $=\mathrm{Sib}(+) \operatorname{sib}(+)$ bi(七); Sib sib bi $\rightarrow$ Seob seob i; 섭 섭이(Someone who used to be well disappointed) (The original meaning.)

'The aged man (woman).' (The current meaning.)

$0081 \mathrm{Go}$ (告): "I am(You are, He is, She is, They are) tremendously angry with the unjust thing!"

$\mathrm{Go}$ (告) $=\mathrm{Wu}($ (牛) gu(口) $\rightarrow \mathrm{Eog}$ ul; 억 울 하다(Suffering unfairness),

Go (告) $=\mathrm{Wu}($ 牛) gu(口) $\rightarrow$ Wug; 욱!(The condition of being very angry to something or somebody) (The original meaning.)

'I proclaim the thing.' (The current meaning.)

$0082 \mathrm{Go}($ 告)(2): "Somebody make me to be in a deep sorrow, so I am crying with the sound of Woo hoo!"

Here, the pronunciation of $\mathrm{Go}$ (古) was changed into Hoo(古).

$\mathrm{Go}_{\mathrm{O}} \mathrm{Wu}($ (牛) hoo(古); Wu hoo $\rightarrow$ Wu heug!; 우 흑!(The sound of weeping voice) (The original meaning.)

'I proclaim the thing.' (The current meaning.)

$0083 \mathrm{Du}$ (斗): "The quantity is twenty(20)." Du(斗) is the measure of quantity for wheat, barley and rice, and it is as same as 20 Doe(the measure of quantity of about 1.8 liters).

$\mathrm{Du}($ 斗) = I(二) sib(十); I sib, 이십(Twenty) (The original meaning.)

'The quantity of this unit is about 18 liters.' (The current meaning.)

0084 Yeong(英): "lt is really good!"

Yeong(英) = Tcho(草) ang(央); Tcho ang $\rightarrow$ "Zo a!”; “좋아!” (very good!) (The original meaning.)

'The flower blooms.' (The current meaning.)

$0085 \mathrm{Ae}$ (哀): "Oh my goodness!"

$\mathrm{Ae}($ 哀): = Eui(衣) gu(口) $\rightarrow$ "Ae gu!"; "애구!" or "Ai go!"; "아이고!". These two words express the sounds when people weep in Korea (The original meaning.)

'It is sad.' (The current meaning.)

As a conclusion, Korean languages were found in Chinese characters. Therefore, it was considered that ancient Koreans have created the Chinese characters. 


\section{ACKNOWLEDGEMENTS}

The researchers thank Mrs Hilye Sarah Kim and Mr Yeonghag Park, Mrs Bohwa Kim and Mr Ilsoo Joseph Kim and Ms Jieun Agatha Kim. We thank Father Jean Blanc, Father Hifumi Iwazaki, Mrs Tamako Hayashi and Mr Yoshihiro Hayashi, Professor Francine Tenaillon and Professor Nicolas Tenaillon. We thank the founder, Dr Bo-yeon Lee and the president, Professor Sangheon Um, the students of Department of Companion Animal and Animal Resources Science in Joongbu University and the members of Daejeon Ludovich of Ordo Franciscanus Saecularis (OFS).

\section{References}

1. Dallet, C. H. (1874). Histoire de l'Eglise de Coree (History of Korean Catholic Church). Victor Palme. Paris. France. 11-99.

2. Fairbank, J. K., \& Reischauer, E. O. (1989). China: tradition \& transformation (Vol. 57). Boston: Houghton Mifflin Company. $17-6$ 5.

3. Park, H. R., Kim, J.A., Kim, K. D. A., Kim, J. A., Kim, S. T., Kim, R., \& Kim, S. A. (2017). Ancient Koreans petition to God in Tcheonzamun: The thousand character essay poem (641st to 656th letters). Journal of Languages and Culture, 8(6), 79-84.

4. Park, H. R., Kim, K. D. A., Kim, J. A., Kim, S. T., Kim, R., Hamon, A., \& Kim, S. A. (2019). The Story of Chinese Characters (0011-0020) When Translated On Korean Pronunciation. South Asian Res J Human Soc Sci, 1(3), 209-211. 